\title{
Peran dan Fungsi Wali Kelas dalam Pembinaan Perilaku Siswa di SMP Negeri 33 Padang
}

\author{
Elvira Petriani, Azwar Ananda \\ Program Studi Pendidikan Pancasila dan Kewarganegaraan \\ Universitas Negeri Padang \\ Email : Elvirapetriani22@gmail.com
}

\section{ABSTRAK}

Artikel ini bertujuan untuk mendeskripsikan peran dan fungsi wali kelas dalam pembinaan perilaku siswa di SMP Negeri 33 Padang. Informan penelitian ini adalah kepala sekolah SMP Negeri 33 Padang, wakil kepala sekolah sekolah bidang kesiswaan, dan wali kelas SMP Negeri 33 Padang. Data penelitian ini diperoleh melalui observasi, wawancara, dan studi dokumentasi. Hasil penelitian ini pelaksanaan peran wali kelas dalam melakukan pembinaan perilaku siswa di SMP Negeri 33 Padang adalah pembinaan perilaku siswa melalui mengumpulan data, fakta dan informan tentang siswa, Pemanggilan orang tua siswa/wali peserta didik dan Menggelola kelas sedangkan pelaksanaan fungsi wali kelas dalam melakukan pembinaan perilaku siswa di SMP Negeri 33 Padang adalah wali kelas memberikan pembinaan perilaku siswa melalui motivasi kepada siswa, menyelanggarakan administrasi kelas, dan pembagian rapor setiap semester. Terdapat beberapa kendala yang dihadapi oleh wali kelas dalam melakukan pembinaan perilaku siswa di SMP Negeri 33 Padang. kendala tersebut berasal dari dua pihak yaitu pihak siswa dan pihak wali kelas. Adapun kendala dari pihak siswa ialah perilaku siswa yang tidak memberikan surat panggilan orang tua kepada orang tuanya sehingga orang tua tersebut tidak memenuhi panggilan dari pihak sekolah dalam rangka mendiskusikan perilaku anaknya. Kendala lain yakni kurangnya kepercayaan orang tua terhadap laporan dari sekolah mengenai perilaku anaknya karena bagi orangtua tersebut perilaku anaknya tidak pernah bermasalah. Sedangkan kendala dari pihak wali kelas ialah banyaknya jam pembelajaran bagi wali kelas, wali kelas hanya sibuk dengan kehadiran dan nilai siswanya tanpa melakukan menelusuri penyebabnya secara mendalam. Upaya wali kelas dalam melakukan pembinaan pada siswanya di SMP Negeri 33 Padang yakitu melakukan pembinaan perilaku siswa melalui pendekatan terhadap siswa serta mengkomunikasikan perilaku siswa dengan orang tuanya.

Kata Kunci: wali kelas, pembinaan perilaku, siswa

\section{ABSTRACT}

This article aims to describe the role and functions of the homeroom in coaching student behavior in SMP Negeri 33 Padang. The informants are the principal of SMP Negeri 33 Padang, vice-principal of the school field of student affairs, and homeroom SMP Negeri 33 Padang. The research data was collected through observation, interviews, and documentation. The results of this research includes the role of the guardian class in fostering student behavior 
in SMP Negeri 33 Padang is coaching the student's behavior through gathering data, facts and informants about students, summons the parents / guardians of students and menggelola class while the execution of the function homeroom in fostering student behavior in SMP Negeri 33 Padang is providing guidance homeroom student behavior through motivation to students, conducting a class administration, and distribution of report cards each semester. There are several obstacles faced by homeroom in fostering student behavior in SMP Negeri 33 Padang. The constraints derived from the two parties, ie the part of students and the homeroom. The constraints of the student is the student's behavior that does not give parents a call letter to the parents so that the parents did not meet the call from the school in order to discuss their children's behavior. Another obstacle which is the lack of confidence of parents to report on the behavior of their children from school because the parents are their children's behavior is never a problem. While the constraints of the guardian class is the number of instructional hours for homeroom, homeroom just busy with the presence and value of their students without trace in depth the cause. Homeroom efforts in fostering the students at SMP Negeri 33 Padang yakitu fostering students' behavior through the approach to students and communicate student behavior with parents.

Keywords : guardian class, development, behaviour, students

This work is licensed under the Creative Commons Attribution-ShareAlike 4.0 International License. @2019 by author and Universitas Negeri Padang.

\section{PENDAHULUAN}

Wali kelas adalah guru yang mendapatkan tugas sampingan dalam mendampingi kelas tertentu. Seorang yang menjabat sebagai wali kelas tentu menjadi orang tua kedua bagi siswa,. Maka seharusnya wali kelas tersebut lebih memiliki kedekatan secara emosional dengan siswanya dan paham akan karakter masing-masing siswa didalam kelasnya. Tugas wali kelas tidak hanya mengajar di dalam kelas tetapi juga memberikan bimbingan di luar kelas, khususnya siswa yang kesulitan, baik kesulitan dalam pembelajaran maupun masalah yang dihadapi siswa. Menurut Soetjipto (2011:102) wali kelas merupakan personal sekolah yang ditugasi untuk menangani masalahmasalah yang dialami oleh siswa yang menjadi binaannya. Ini berarti bahwa seseorang wali kelas harus memimpin kelasnya yang tidak hanya terbatas dalam kelas tetapi juga di luar dalam kelas. Kegiatan di dalam kelas menyangkut personal anak didik.

Berdasarkan standar operasional prosedur peran dan fungsi wali kelas di SMP Negeri 33 Padang diantaranya sebagai berikut menerima SK merencanakan Program bimbingan konseling, pencatatan data siswa, memberikan bimbingan rutin, penyelesaikan permasalahan siswa, mengisi rapor siswa, dan memberikan motivasi kepada siswa. Peran wali kelas dalam melakukan pembinaan kepada siswa dengan berbagai bentuk yaitu melakukan pengumpulan data siswa, fakta dan informan tentang siswa seperti nilai siswa, laporan hasil observasi siswa dan lain sebagainya. Wali kelas mempu menggelolahan kelas dengan menciptaka senyaman, 
menyenangkan dan nyaman dalam wakti pembelajaran. Berdasarkan permasalah yang terjadi di SMP Negeri 33 Padang peran wali kelasnya melakukan mengumpulan data siswa, membuat atau merangkap nilai siswa, tetapi kurang melakukan pembinaan kepada siswanya. Kebanyakkan wali kelas melakukan observasi, hasil pembelajaran. Sedangkan fungsi wali kelas melakukan penyelengarakan administrasi kelas, memberikan motivasi, mengisi lapor siswa.

Ada pun permasalah yang dihadapi wali kelas berdasarkan tingkat permasalahan. Di SMP Negeri 33 Padang ada sebagai guru yang ditugaskan menjadi wali kelas. Jumlah wali kelas di SMP Negeri 33 Padang adalaha 16 orang. 6 orang wali kelas VII, VIII dan VIII. Setiap tingkatan permasalahan yang dihadapi wali kelas berbeda-beda. Jumlah siswa di SMP Negeri 33 Padang adalah 559 siswa.

Ada pun bentuk permasalahan di SMP Negeri 33 Padang yakitu permasalahan kelas VII diantaranya iaiah siswa tersebut belum menyesuaikan dirinya dalam kehidupan baru. Karena masih ada perubahan kekanak-kanakan menuju remaja. Maka peran dan fungsi wali kelas sangat diperlukan untuk membina perilaku, budi pekerti dan kepribadian anak didiknya. menjadi wali kelas VII ada juga wali kelas tidak mengenal siswa dan tidak tahu permasalahan siswa dikelasnya, dan selain itu juga ada juga yang tidak tahu peran dan fungsi wali kelasnya hanya sebagai yang tahun.

Permasalahan pada wali kelas VIII diantaranya ialah banyak konflik terjadi pada siswa dan juga kurangnya sopan cara berbicara siswa dengan teman sebanyanya. Selain itu siswa juga kurang displin baik dalam segi kedatanga siswa maupun dalam pembelajaran. Pada wali kelas yang tidak kenal dengan siswanya dan selain itu juga wali kelas kurang penuli dengan permasalah siswa. Hal tersebut membuat siswa kurang mendapat perhatian dan pembinaan wali kelas. Permasalahan pada kelas IX diantaranya ialah terdapat pada masalah motivasi belajar, hubungan dengan teman sebanya. Sehingga peran dan fungsi wali kelas IX lebih difokuskan dengan pembinaan perilaku selain itu juga dengan mengembangkan keterampilan dan kecerdasan.

Berdasarkan tiga permasalahan diatas, peneliti melihat peran dan fungsi wali kelas dalam membinaan perilaku siswa di SMP Negeri 33 Padang lebih memfokuskan pada kelas VIII karena permasalahan di kelas VIII sangat banyak, selain itu melihat bagaimana peran dan wali kelasnya, permasalahan salah satunya yakitu cabut, bolos, kurang sopan terhadap guru, berbicara dengan teman sebaya banyak saling bullying, mencontek ketika diberi tugas oleh guru mata pelajaran dan lain sebagainya.

Masalah yang terjadi di SMP Negeri 33 Padang sering terjadi siswanya bolos sekolah karena kurang terkontrolnya siswa di lingkungan sekolah tersebut sehingga peran guru dan wali kelas sangat perlu dalam membina perilaku siswa-siswanya baik diluar kelas maupun didalam kelas itu sendiri. Penelitian terdahulu tentang peran dan fungsi wali kelas dalam pembinaan perilaku siswa 
(Mustika, Zahra. 2015). Peran wali kelas dalam pembelajaran. Penelitian terdahulu tersebut bertujuan untuk meningkatkan motivasi belajar siswa, sedangkan penelitian ini adalah bertujuan mendeskipsikan bagaimana peran dan fungsi wali kelas dalam pembinaan perilaku siswa.

SMP Negeri 33 Padang peran dan fungsi wali kelas belum berjalan dengan baik. Dimana catatan perilaku siswa banyak yang bermasalah. Oleh karena itu penelitian ini akan mendeskipsikan peran dan fungsi wali kelas dalam pembinaan perilaku siswa di SMP Negeri 33 Padang.

\section{METODE PENELITIAN}

Penelitian ini menggunakan penelitian kualitatif deskripsi, bertujuan untuk mendeskripsikan peran dan fungsi wali kelas dalam pembinaan perilaku siswa di SMP Negeri 33 Padang. Data ini dikumpulan melalui observasi, wawancara dan studi dokumentasi yang dipilih melalui teknik purposive sampling. Informan penelitian ini ialah kepala sekolah SMP Negeri 33 Padang. Wakil kepala sekolah bidang kesiswaan, guru BK SMP Negeri 33 Padang, Guru wali kelas VIII SMP Negeri 33 Padang. Peneliti juga menggunakan alat perekam, kamera dan buku catatan untuk mengabadikan hasil penelitian yang diperoleh dilapangan. Teknik analisis data ialah sebagai berikut. Pengumpulan data, reduksi data, penyajian data, dan penarik kesimpulan data dan verifikasi. Untuk melakukan pengujian keabsahan data peneliti menggunakan teknik triangulasi sumber dan triangulasi teknik.

\section{HASIL DAN PEMBAHASAN}

Seorang guru yang menjabat sebagai wali kelas dalam melakukan pembinaan perilaku siswa, mempunyai peran dan fungsi Mengumpulan data, fakta dan informan tentang siswa, Pemanggilan orang tua siswa/wali peserta didik dan Menggelola kelas sedangkan pelaksanaan fungsi wali kelas dalam melakukan pembinaan perilaku siswa di SMP Negeri 33 Padang adalah wali kelas memberikan motivasi kepada siswa, menyelanggarakan administrasi kelas,dan pembagian rapor setiap semester. Sebagaimana di ungkapkan oleh Gibson dan Mitchen (2010) ini merupakan mengenai peran wali kelas dan tanggung jawab wali kelas dalam melakukan penyelenggaran bimbingan dan konseling di sekolah yaitu memberikan nasehat kepada siswa, baik didalam kelas mau pun di luar kelas.

Peran wali kelas dalam pembinaan perilaku siswa di SMP Negeri 33 Padang Dalam melakukan pembinaan perilaku siswa melalui mengumpula data fakta dan informan tentang siswa. Wali kelas mendata kembali siswa secara individu, membuat sebuah arsip, supaya wali kelas mudah menemukan identitas siswa, untuk membuat rapor atau isi rapor oleh wali kelas.

Peran wali kelas dalam melakukan pembinaa perilaku siswa harus ada kerja sama antara wali kelas dengan orang tua siswa atau keluarga siswa. Keluarga merupakan tempat pertama dan utama bagi pertumbuhan dan perkembangan seorang anak. Menurut majelis umum PBB (dalam megawangi, 2003) bahwa fungsi utama keluarga adalah sebagai wahana untuk mendidik, mengasuh dan 
Volume 1 No. 32018

mensosialisasikan anak, mengembangkan kemempuan seluruh anggotanya agar dapat menjalankan fungsi dimasyarakat dengan baik, serta memberikan kepuasan dan lingkungan yang sehat guna tercapainya keluarga, sejahterah. Sedangkanmenurut pakar pendidikan, Wiliam Bennett (dalam Megawangi, 2003) keluarga merupakan tempat yang paling awal dan efektif untuk menjalankan fungsi Departemen Kesehatan, Pendidikan dan Kesejahteraan. Apabila keluarga gagal untuk mengajarkan kejujuran, semangat, keinginan untuk menjadi yang terbaik, dan kemampuan dasar, maka akan sulit sekali bagi institusi lain untuk memperbaiki kegagalankegagalannya. Maka dari itu wali kelas ada melakukan komunikasi orang tua murid tentang perilaku anaknya, supaya orang tua ada pegawasan tentang perilaku anaknya dirumah. Keberhasilan anak tergantung orang tua dirumah dalam mendidiknya.

Peran wali kelas melakukan pembinaan perilaku siswa melalui penggelolaan kelas, terutama ditentukan oleh proses belajar mengajar yang berlangsung diruang kelas. Dalam proses belajar mengajar tersebut guru memegang peran yang sangat penting. Guru adalah creator proses belajar mengajar. Maka dari itu guru atau wali kelas perlu menata dan menggelola lingkungan kelas, sehingga menimbulkan suasana belajar yang menyenangkan bagi siswa dan menghindari siswa dari kejenuhan.

Oleh karena itu beberapa hal yang dapat dijadikan untuk melakukan menggelola kelas yang baik yakitu menciptakan atmosfir belajar, pengaturan meja dan kursi, pengaturan posisi tempat duduk siswa memiliki dampak yang sangat besar, karena setiap dua bulan wali kelas melakukan pergantian tempat duduk siswa, supaya siswa tersebut dapat berkomunikasi dan menciptaka rasa kekeluargaan, baik disegi siswa maupun dengan guru. Maka dari itu wali kelas dapat melakukan pengaturan tempat duduk siswa harus berdasarkan psikologi siswa.

Fungsi Wali kelas memberikan motivasi kepada siswanya, baik motivasi dalam waktu belajar maupun diluar jam belajar. Memberikan motivasi sangat perlu diberikan oleh peserta didik, karena dengan adanya motivasi belajar siswa bersemangat untuk belajar, untuk mengapai citacita masa yang akan datang. Motivasi pembelajar dapat meningkatan semangat belajar siswa. Hal ini sesuai dengan pendapat Sardiman (2010:75) bahwa motivasi adalah sebagai keseluruhan daya penggerak didalam diri siswa yang menimbulkan kegiatan belajar. Sedangkan Mulyasa (2003:121) mengatakan bahwa motivasi adalah keinginan yang menggerakan atau mendorong seseorang atau diri sendiri untuk berbuat sesuatu.

Maka dapat disimpulkan dengan adanya motivasi yang tepat dari seorang guru dapat membangkitkan semangat dan mendorong siswa untuk melakukan kegiatan yang baik, sedangkan hasil dari pembelajaran tercapai dengan optimal. Dengan kata lain motivasi dapat meningkatkan prestasi siswa. Selain itu juga wali kelas memberikan motivasi kepada siswa yang sering cabut dan alfa. Karena dengan cara ini siswa dapat membangkitan kembali semangat datang sekolah. 
Fungsi wali kelas dalam pembinaan perilaku siswa melalui menyelenggarakan administrasi kelas. Ini merupakan fungsi awal menjadi wali kelas, wali kelas berhak mengatur dan menghias kelasnya dan nyaman untuk proses pembelajaran. Maka dari itu wali kelas melakukan pembinaan perilaku siswa melalui menyelenggarakan administrasi kelas seperti membuat tempat denah duduk siswa, buat daftar piket siswa, membuat daftar pembelajaran siswa, membuat struktur pengurus kelas, membuat tata tertib siswa, membuat buku kecil dan batas pembelajaran.

Wali kelas berhak membuat peraturan dan tidak bertentang dengan peraturan sekolah. Sebab peraturan sekolah menjadi patokan dan memberikan pengaruh besar. Sejalan dengan apa yang disebutkan oleh Fitriana Daely (2014), bahwa penerapan peraturan sekolah yang bersifat umum dikategorikan cukup diterapkan oleh siswa terlihat dalam aspek dilarang untuk melakukan halhal yang menyimpang dari kegiatan pembelajaran harus seizin guru, tidak keluar kelas jika tidak ada izin dari guru, dan mendengarkan dengan baik apa yang dikatakan atau diperintah oleh guru. Kemudian penerapan peraturan sekolah pada standar atau aktifitas khusus cukup diterapkan oleh siswa terlihat dalam aspek memakai pakaian seragam yang baik dan benar, mengerjakan laboratorium dengan baik, mengerjakan perkerjaan rumah (PR) yang diberikan oleh guru.

Fungsi wali kelas lainnya adalah memberikan rapor kepada orang tua siswa. Orang tua siswa sangat berhak tahu hasil pembelajaran dan tingkah laku siswanya. Wali kelas merupakan orang tua kedua bagi siswa disekolah, maka orang tua siswa berhak mengetahui perkembangan anaknya. Maka dari itu wali kelas memberitahukan kepada orang tua perilaku anaknya. Didalam hasil rapor siswa adanya isinya tentang perilaku siswa. Penilaian ini wajib diisi oleh wali kelas. Sebagai bentuk pelaporan kepada orang tua siswa dalam bentuk rapor mengenai perilaku siswa selama disekolah.

Berdasarkan hasil penelitian yang dilakukan dilapangan adapun kendala-kendala yang dihadapi oleh seorang wali kelas dalam melakukan pembinaan perilaku siswa di SMP Negeri 33 Padang. Siswa menunjukan sikapnya berbeda di sekolah dan dirumah sehingga orang tua siswa tidak percaya bahwa anaknya melakukan perbuatan dan sikap yang kurang baik. Maka pembinaan yang dilakukan kepada siswa tersebut. Dengan melakukan kerja sama antara orang tua dengan pihak sekolah tidak terwujud. Dikarena ada perbuatan tingkah laku adan sikap siswa dirumah dan disekolah sangat berbeda, dan Siswa tidak memberikan surat pemanggilan orang tua, sehingga siswa hanya dinasehati oleh wali kelas. Maka pengawasana antara wali kelas dan orang tua tidak terwujud dengan baik.

Di sisi lain wali kelas sangat disibukkan dengan jam mengajarnya, ini juga mengakibatkan kurang intensitas waktu yang dimiliki oleh wali kelas dengan siswa yang dibinaannya. Karena wali kelas hanya memiliki waktu dengan binaannya hanya diwaktu jam mengajar saja. Sehinggan dalam melakukan pembinaan kurang terwujud di karenakan wali kelas disibukan 
dengan jam mengajar. Tentunya wali kelas sibuk dengan jam mengajarnya sehingga nasehat dan pengarahan dari wali kelas tidak terleksana dengan baik. Hal ini juga menyebabkan pemahaman wali kelas terhadap karakteristik siswa.

Wali kelas hanya sibuk dengan kehadiran siswa, nilai siswanya tanpa melakukan menelusuri penyebabnya secara mendalam. Berdasarkan pernyataan dari siswa, mereka tidak datang kesekolah di karenaka ada beberapa alasan, selain itu juga tidak sempat buat surat. Tetapi wali kelas kurang mengerti tentang hal ini. Wali kelas hanya melihat kehadiran siswa yang secara tertulis dan kurang melakukan pembinaan. Wali kelas kurang memberikan nasehat terhadap nilai siswa yang buruk dan kurang memberikan motivasi kepada siswanya. Wali kelas memberikan motivasi kepada siswa secara umum. Sedangkan memberikan motivasi secara individu kurang. Seharusnya wali kelas memberikan motivasi secara individu, karena permasalahan setiap individu berbeda-beda. Supaya permasalahan siswa dapat diselesaikan dengan baik.

Upaya wali kelas dalam melakukan pembinaan perilaku pada siswa di SMP Negeri 33 Padang adalah sebagai berikut. Melakukan pendekatan terhadap siswa. Mengkomunikasikan perilaku anaknya antara wali kelas dan orang tuanya. Pendekatkan terhadap siswa dapat dilakukan pendekatan secara emosional, setelah itu wali kelas melakukan diskusi dengan siswa tersebut tentang permasalahan siswa baik dalam bentuk perilakunya. Dalam rangka Mengkomunikasikan perilaku anaknya, wali kelas memanggil orang
Volume 1 No. 32018

tuanya. Untuk mendiskusikan permasalahan atau perbuatan perilaku anaknya. Supaya ada kerja sama untuk melakukan perubahan perilaku anak. Tidak sepenuhnya di serahkan kepada pihak sekolah. Sedangkan orang tua juga ada pengawasan.

\section{KESIMPULAN}

Berdasarkna temuan hasil penelitian dan pembahasan yang telah dilakukan dapat disimpulkan bahwa pelaksanaan peran dan fungsi wali kelas dalam pembinaan perilaku siswa di SMP Negeri 33 Padang adalah pembinaan yang dilakukan melalui Mengumpulan data, fakta dan informan tentang siswa, Pemanggilan orang tua siswa/wali peserta didik dan Menggelola kelas sedangkan pelaksanaan fungsi wali kelas dalam melakukan pembinaan perilaku siswa di SMP Negeri 33 Padang adalah wali kelas memberikan pembinaan perilaku siswa melalui motivasi kepada siswa, menyelanggarakan administrasi kelas,dan pembagian rapor setiap semester. Kendala yang dihadapi wali kelas dalam melakukan pembinaan perilaku siswa di SMP Negeri 33 Padang yakitu Kurang kepercayaan orang tua terhadap laporan perilaku anaknya dan kurangnya kepedulian orang tua terhadap pemanggilan pihak sekolah untuk mendiskusikan perilaku anaknya. Upaya wali kelas dalam melakukan pembinaan pada siswanya di SMP Negeri 33 Padang yakitu Melakukan pendekatan terhadap siswa dan mengkomunikasikan perilaku anaknya antara wali kelas dan orang tuanya. 


\section{DAFTAR PUSTAKA}

Ashram, H. Peran Wali kelas dalam membentuk perilaku siswa di Sdn 7 Bungtiang tahun 2013.

Eswendi.2015.Bahan Ajar Metode Penelitian.Padang: UNP Press.

Fitri Mahdalena. Peran Wali Kelas Dalam Pengelolaan Kelas Di Smp Negeri 14 Banda Aceh. Universitas Islam Negeri ArRaniry Darussalam-Banda Aceh.

Mega Iswari, membina perkembangan emosi remaja meningkatkan profesional guru. Julnal ilmiah ilmu pedidikan volume IX No.1 April 2009.

Soetjipto,raflis kosasi. 2011. Profesi keguruan. Jakarta : PT Asdi Mahasatya

Sugiyono.2011. Metode penelitian kuantitaf kualitaif dan R\&D. Bandung: Alfabeta.

Sugiyono.2012. Metode penelitian kuantitaf kualitaif dan R\&D. Bandung : Alfabeta.

Syamsudduha, St. Partisipasi Orang Tua Dalam Pendidikan Anak Di Sekolah Pada SDIT AL-FITYAN Kabupaten GOWO. Jurnal AlKalam, Vol IX, No 2 Desember 2017

Suryani, Eli. 2018. Peran Wali Kelas Dalam Mengatasi Masalah Kesulitan Belajar Siswa Di Min Glugur Darat II Kecematan Medan Timur Tahun Ajaran 2017/20s18. Universitas Islam Negeri. Medan

Zahara mustika. Pentignya peran wali kelas dalam pembelajaran dalam pembelajaran. Jurnal volume 3, no.1, januari-juni 2015

Syamsudduha, St. Partisipasi Orang Tua Dalam Pendidikan Anak Di
Sekolah Pada SDIT AL-FITYAN Kabupaten GOWO. Jurnal AlKalam, Vol IX, No 2 Desember 2017

Suryani, Eli. 2018. Peran Wali Kelas Dalam Mengatasi Masalah Kesulitan Belajar Siswa Di Min Glugur Darat II Kecematan Medan Timur Tahun Ajaran 2017/20s18. Universitas Islam Negeri. Medan. 